\title{
Effects of Organic Carbon Supply Rates on Mobility of Previously Bioreduced Uranium in a Contaminated Sediment
}

Jiamin Wan ${ }^{1 *}$, Tetsu K. Tokunaga ${ }^{1}$, Yongman Kim ${ }^{1}$, Eoin Brodie ${ }^{1}$, Rebecca Daly ${ }^{2}$, Terry C. Hazen $^{1}$, Mary K. Firestone ${ }^{2}$

${ }^{1}$ Lawrence Berkeley National Laboratory, Berkeley, California 94720;

${ }^{2}$ University of California, Berkeley, California 94720

Abstract Bioreduction-based strategies for remediating uranium (U)-contaminated sediments face the challenge of maintaining the reduced status of $U$ for long times. Because groundwater influxes continuously bring in oxidizing terminal electron acceptors $\left(\mathrm{O}_{2}, \mathrm{NO}_{3}{ }^{-}\right)$, it is necessary to continue supplying organic carbon (OC) to maintain the reducing environment after $\mathrm{U}$ bioreduction is achieved. We tested the influence of OC supply rates on mobility of previously microbial reduced uranium $\mathrm{U}(\mathrm{IV})$ in contaminated sediments. We found that high degrees of $\mathrm{U}$ mobilization occurred when OC supply rates were high, and when the sediment still contained abundant Fe(III). Although 900 days with low levels of OC supply minimized U mobilization, the sediment redox potential increased with time as did extractable $\mathrm{U}(\mathrm{VI})$ fractions. Molecular analyses of total microbial activity demonstrated a positive correlation with OC supply and analyses of Geobacteraceae activity (RT-qPCR of 16S rRNA) indicated continued activity even when the effluent $\mathrm{Fe}$ (II) became undetectable. These data support our earlier hypothesis on the mechanism responsible for re-oxidation of microbial reduced U(IV) under reducing conditions; that microbial respiration caused increased (bi)carbonate concentrations and formation of stable 
uranyl carbonate complexes, thereby shifted $\mathrm{U}(\mathrm{IV}) / \mathrm{U}(\mathrm{VI})$ equilibrium to more reducing potentials. The data also suggested that low OC concentrations could not sustain the reducing condition of the sediment for much longer time.

\section{INTRODUCTION}

Production of nuclear weapons and fuel have left soils and sediments at many locations contaminated with toxic levels of $U$. The mobility of $U$ in the subsurface depends strongly on its oxidation state, the presence of terminal electron acceptors (TEAs), and the concentrations of complexants. When reduced to U(IV) Uranium becomes much less soluble, and when oxidized to $\mathrm{U}(\mathrm{VI})$, and especially when strong complexants such as carbonate are present, its solubility is high (1). Earlier studies demonstrated that U(VI) can be reduced by some Fe- and S-reducing bacteria, both enzymatically and indirectly (2-5). Based on these findings, U remediation strategies are under development that rely on injecting organic carbon (OC) into contaminated sediments to stimulate microbial U(VI) reduction to lower solubility U(IV) minerals (6-8). Because long-term stability of microbially reduced $\mathrm{U}(\mathrm{IV})$ (permanent $\mathrm{U}$ reduction or very low release rates into the biosphere) is critical for the success of this potential technology, it is important to understand factors that influence $\mathrm{U}$ mobility during remediation.

Dissolved oxygen, nitrate and denitrification products have been demonstrated to mobilize U through oxidization of U(IV) (9-12). Because groundwater influxes bring dissolved oxygen and nitrate into the subsurface, continuous or periodic injection of OC will be required after $U$ bioreduction is completed in order to maintain the reducing environment. It has been believed that when influxes of highly oxidizing TEAs (especially $\mathrm{O}_{2}$ and $\mathrm{NO}_{3}^{-}$) are prevented, $\mathrm{U}(\mathrm{IV}$ ) is stable in reducing sediments. However, this key assumption underlying in situ U bioremediation strategies has been challenged by results from our recent study (13). Through a relatively longterm (510 day) column experiment under controlled, environmentally relevant conditions, we 
found that microbially reduced $U$ was re-oxidized under sustained reducing conditions. It was hypothesized that the increased $\mathrm{CO}_{2}$ partial pressure $\left(\mathrm{P}_{\mathrm{CO} 2}\right)$ and carbonate concentration caused by microbial respiration shifted $\mathrm{U}(\mathrm{IV}) / \mathrm{U}(\mathrm{VI})$ equilibrium to lower redox potentials through formation of strong $\mathrm{U}(\mathrm{VI})$-carbonate complexes (2). This present study addresses the question of whether or not U(IV) remobilization could be avoided, and the impacts of different OC supply rates after the $\mathrm{U}(\mathrm{VI})$ bioreduction was completed. We continued the column experiments that yielded the aforementioned results for an additional 890 days with varied OC supply rate. In this paper we refer to the experiments up to 510 days as "Phase I", and the experiments from 510 to 1400 days as "Phase II".

\section{METHODS}

Sediment Columns. A historically U-contaminated sediment from "Area 2" of the U. S. Department of Energy Environmental Remediation Management Program's Field Research Center in Oak Ridge National Laboratory, Tennessee, was packed into the replicate columns. Before packing, the fresh sediment was extruded through a $5.6 \mathrm{~mm}$ sieve to remove the coarse gravel fraction, and then homogenized. The preparation was performed under a $\mathrm{N}_{2}$ atmosphere. The homogenized sediment had a $U$ concentration of $206 \mathrm{mg}(\mathrm{kg} \text { sediment })^{-1}$. This sediment consisted of $30 \%$ sand and fine gravel $(50 \mu \mathrm{m}-5.6 \mathrm{~mm}), 41 \%$ silt $(2-50 \mu \mathrm{m})$, and $29 \%$ clay $(<2$ $\mu \mathrm{m}$ ). The sediment contained 3.0 mass $\%$ of $\mathrm{CaCO}_{3}$ (pressure calcimetry, sediment reacted with $2 \mathrm{~N} \mathrm{HCl}$ ). The $\mathrm{pH}$ of the water extract (water:sediment mass ratio $=1: 1$ ) was 7.9. The major element composition of the sediment can be found in Wan et al. (13). The sediment was packed into columns to a bulk density of $1.48 \mathrm{Mg} \mathrm{m}^{-3}$ (porosity $=0.45$ ). Columns were $200 \mathrm{~mm}$ long, 32 mm I.D., and made of polycarbonate pipe. Redox potential measurements were obtained in sediments through 6 Pt electrodes embedded along the length of each column. Influent solutions 
were infused from the bottom of vertically oriented columns. The column effluents were continuously discharged into a fraction collector.

Procedure for the Column Experiments. The influent OC concentration was varied from the original $32 \mathrm{mM}$ going into all columns in Phase I to 100, 32, 6, and $0 \mathrm{mM}$ for the 4 columns tested in Phase II, respectively. A constant fluid velocity of $10 \mathrm{~mm} \mathrm{~d}^{-1}$ was used, which resulted in supply rates of $560,180,34$, and $0 \mathrm{mmol}$ OC $(\mathrm{kg} \mathrm{sediment})^{-1} \mathrm{y}^{-1}$ for the four different influent OC concentrations. Because the flow rate was constant, we will refer to influent OC concentrations, rather than rates of OC delivery. To assure long-term anoxic performance, columns were placed in a $\mathrm{N}_{2}$ glove box. Sodium lactate as the sole OC source was added to a simulated groundwater ( $\left.1 \mathrm{mM} \mathrm{NaCl}, 1 \mathrm{mM} \mathrm{CaCl}_{2}, 1 \mathrm{mM} \mathrm{MgCl}_{2}, 1 \mathrm{mM} \mathrm{KCl}, \mathrm{pH} 7.2\right)$, but oxidants was excluded for simplicity (except that influents were not degassed, and thus contained $0.14 \mathrm{mM} \mathrm{O}_{2}$ ). Near the end of the experiment (D1080), 3 pore volumes (PV) of air-equilibrated influents were injected (containing $0.26 \mathrm{mM} \mathrm{O}_{2}$ ) to test the impact of increased TEA supply on $\mathrm{U}$ stability after a long period of OC injection. Concentrations of U (kinetic phosphorimetry, KPA, Chemchek), OC and inorganic carbon (TIC-TOC analyzer, O-I Analytical) were measured in effluents. Samples for measurements of effluent Fe and Mn concentrations were periodically collected into acidified vials and measured using ICP. A total of $70 \mathrm{PV}(\sim 80 \mathrm{~mL} / \mathrm{PV})$ were infused through the columns over a 3.8 years period of time. OC concentrations of inflow solutions at different intervals of time are listed in Table 1. In this table, days zero to 510 constitute Phase I, in which all the columns received $32 \mathrm{mM} \mathrm{OC} \mathrm{(10.7} \mathrm{mM} \mathrm{lactate).} \mathrm{In} \mathrm{Phase} \mathrm{II,}$ starting from D510 each column received a different OC concentration, and some columns were subjected to further variations in OC at later times. At the end of the experiments (D1400), each column was sectioned into five segments. A sediment sample was taken from each segment for analyses of HCl-hydroxylamine extractable Fe(II) and Fe(III) (14), carbonate extractable U(VI) (15), and molecular analyses of microbial biomass and activity. 
Extracting Sediment Iron. The sediment sampling and iron extraction were conducted under anaerobic conditions. A HCl-hydroxylamine method (14) was used to measure extractable Fe(II) and $\mathrm{Fe}(\mathrm{III})$ on paired sediment samples. To determine $\mathrm{HCl}$-extractable $\mathrm{Fe}(\mathrm{II}), 0.1 \mathrm{~g}$ of sediment was reacted with $5 \mathrm{ml}$ of $0.5 \mathrm{M} \mathrm{HCl}$ solution at room temperature for one hour. After centrifugation, $0.1 \mathrm{~mL}$ of the extract was mixed with $5 \mathrm{~mL}$ of ferrozine $\left(1 \mathrm{~g} \mathrm{~L}^{-1}\right)$ solution buffered by $50 \mathrm{mM}$ HEPES at $\mathrm{pH}$ 7. The suspension was then filtered $(0.2 \mu \mathrm{m}$ polycarbonate filter), and the $\mathrm{Fe}(\mathrm{II})$ concentration was determined by spectrophotometry (absorbance at 562 $\mathrm{nm})$. To determine hydroxylamine-reducible Fe(III), a parallel $0.1 \mathrm{~g}$ sediment sample was used. The sediment sample was extracted using the same procedure as that described above but with a $5 \mathrm{ml}$ extractant solution containing $0.25 \mathrm{M}$ hydroxylamine hydrochloride and $0.25 \mathrm{M} \mathrm{HCl}$. The hydroxylamine reduces $\mathrm{Fe}(\mathrm{III})$ to $\mathrm{Fe}(\mathrm{II})$. The hydroxylamine-reducible $\mathrm{Fe}(\mathrm{III})$ was obtained by subtracting $\mathrm{HCl}$-extractable $\mathrm{Fe}(\mathrm{II})$ (previously described) from this measured total extractable iron. These Fe extraction procedures were performed at three different times during the experimental duration. The original sediment was used for the time point D0. On D900, a sediment sample was taken from the top end of each sediment column after temporarily removing its end-cap within a $\mathrm{N}_{2}$ glove bag. At D1400 (the end of the experiments), each column was sectioned into five segments, and triplicate samples were taken from each segment. For each of aforementioned samples, an accompanying sediment sample set was used for measuring moisture content in order to report Fe concentrations relative to dry sediment mass.

Extractable Sediment U(VI). Concentration changes of carbonate extractable U(VI) in sediments were measured following the procedure of Zhou and Gu (15). About $1.0 \mathrm{~g}$ of wet sediment was transferred into $20 \mathrm{~mL}$ of $0.5 \mathrm{M}$ degassed $\mathrm{Na}_{2} \mathrm{CO}_{3}$ solution. The $\mathrm{pH}$ of the solution was 11.9. Extraction was performed anaerobically. After $65 \mathrm{hrs}$ of stirring the soil suspension and then ultracentrifugation, U concentrations were determined using KPA. 
Molecular analysis of Geobacteraceae populations. Nucleic acids were extracted from anaerobically-sampled sediment sections collected at D1400 from the 100, 6 and $0 \mathrm{mM}$ OC columns. Samples were flash-frozen in liquid $\mathrm{N}_{2}$ and stored at $-80^{\circ} \mathrm{C}$ until extraction. DNA and RNA were extracted using a modification of the Fast DNA SPIN Kit for Soil (MP Biomedicals, Irvine, CA) (see Supporting Information). RNA was reverse transcribed and copy numbers of Geobacteraceae 16S rRNA were quantified by real-time quantitative PCR (see Supporting Information). Correlations between geochemical parameters and $16 \mathrm{~S}$ rRNA copies were performed in the statistical programming environment $\mathrm{R}(16)$.

\section{RESULTS AND DISCUSSION}

\section{Effects of OC Supply Rates on Mobility of Previously Microbial Reduced U. Variations in} effluent $\mathrm{OC}$, inorganic carbon, and $\mathrm{U}$ concentrations from the 4 columns over the 3.8 years are presented in Figures 1a-c. The $\mathrm{pH}$ in effluents remained stable at $7.4 \pm 0.3$ throughout the study. Data of Phase I have been previously reported (13). As these earlier results provide the context for this paper, we summarize salient points from the previous report and the hypotheses that resulted in this follow up paper. In Phase I, all columns had the same influx solution containing $32 \mathrm{mM}$ OC. As microbial respiration oxidized OC (Fig. 1a) into (bi)carbonate (Fig. 1b), effluent U concentrations decreased rapidly (Fig. 1c) to less than $0.03 \mu \mathrm{M}$, well below the U.S. EPA drinking water standard for $\mathrm{U}$ of $15 \mathrm{pCi} \mathrm{L}^{-1}(0.126 \mu \mathrm{M})(17)$. In situ reductive remediation of $\mathrm{U}$ appeared successful at this time. However, beyond 100 days, increased $U$ concentrations in the effluents were observed in all of the columns, and reached steady state at about 200 days with U concentrations raised to about $1 \mu \mathrm{M}$. X-ray absorption spectroscopy of $\mathrm{U}$ oxidation states within the columns provided direct evidence that the $U$ was reduced (measured at day 107) and then was re-oxidized (measured at day 346). Steady methane production indicated that the sediment 
columns were under very reducing conditions. Steady OC utilization by microorganisms and carbonate production indicated that an active microbial population was sustained. We hypothesized that the increases in (bi)carbonate concentrations resulting from microbial respiration caused formation of very stable uranyl carbonate complexes, thereby increasing the thermodynamic favorability of U(IV) oxidation. We also hypothesized that a reactive Fe(III) fraction persisted in the sediment and served as the TEA for U reoxidation. These hypotheses were tested in phase II of this study, in addition to exploring if there is an optimal rate of OC delivery for preventing $U$ remobilization.

Table 1. Inflow OC concentrations at different times for different columns.

\begin{tabular}{|ccccc|}
\hline Days & $1-510$ & $510-720$ & $720-780$ & $780-1400$ \\
Column-Name & & \multicolumn{3}{c}{ [OC] $\mathrm{mM}$} \\
$100 \mathrm{mM}$ & 32 & 100 & 200 & 100 \\
$32 \mathrm{mM}$ & 32 & 32 & 32 & 100 \\
$6 \mathrm{mM}$ & 32 & 6 & 6 & 6 \\
$0 \mathrm{mM}$ & 32 & 0 & 0 & 0 \\
\hline
\end{tabular}

At the beginning of Phase II, the OC supply was switched to 4 different rates; 560, 180, 34, and $0 \mathrm{mmol} \mathrm{OC} \mathrm{kg}^{-1} \mathrm{y}^{-1}$, under a constant flow rate of $0.01 \mathrm{~m} \mathrm{day}^{-1}$. For simplicity, in discussions throughout this paper we use $100 \mathrm{mM}, 32 \mathrm{mM}, 6 \mathrm{mM}$, and $0 \mathrm{mM}$ to refer to the 4 sediment columns, although the OC supply rates were further varied for two of the columns (Table 1). The effluent U, OC, and bicarbonate concentrations collected during the 2.4 year Phase II study are also presented in Figures 1a-c. Clear correlations were observed between the effluent $\mathrm{U}$ and bicarbonate concentrations, with responses proportional to changes in OC supply rates, up to around D800. The effluent $\mathrm{U}$ concentrations increased from $\sim 1 \mu \mathrm{M}$ in Phase I to 5.5 
$\mu \mathrm{M}$ and then to $10 \mu \mathrm{M}$ as $\mathrm{OC}$ increased from $32 \mathrm{mM}$ to $100 \mathrm{mM}$ then $200 \mathrm{mM}$, respectively. During this same time interval, effluent U concentrations remained unchanged for the column 32 $\mathrm{mM}$ with its original OC supply rate kept constant. In contrast, the effluent $\mathrm{U}$ concentrations dropped from $1 \mu \mathrm{M}$ in Phase I to near $0.2 \mu \mathrm{M}$ for the columns $6 \mathrm{mM}$ and $0 \mathrm{mM}$. These two decreased OC supply rates resulted in steep decreases in effluent U concentrations, but did not show significant differences between each other. The changes in effluent bicarbonate concentrations corresponded well to influent OC concentrations and matched the changes of effluent $U$ concentrations. The effluent $\mathrm{OC}$ concentrations remained low, $\sim 1 \mathrm{mM}$ and only increased to $\sim 3 \mathrm{mM}$ when $200 \mathrm{mM}$ OC was injected, indicating near complete microbial consumption of OC. These Phase II data up to $\sim$ D800 provided convincing evidence that excessive OC supply rates promoted reoxidation of bioreduced U(IV) and/or desorption of unreduced $\mathrm{U}(\mathrm{VI})$ through formation of stable U-carbonate complexes. Calculations predicting these complexes and confirmation of their prevalence in column effluents by laser fluorescence spectroscopy were provided previously (13).

Effluent U concentrations declined after about D800, despite continuous OC infusion and consequent high bicarbonate concentrations. A sharp decrease for effluent $U$ in column $100 \mathrm{mM}$ started at $\sim$ D820. Column $32 \mathrm{mM}$ had its influent OC increased to $100 \mathrm{mM}$ on D780, but its effluent $U$ concentrations also declined. The decreased effluent $U$ under sustained high OC supply rates and high bicarbonate concentrations suggested that the U-reoxidation process was no longer significant. Analyses presented later supports the hypothesis that much of the reactive $\mathrm{Fe}(\mathrm{III})$ fraction in the sediment was reduced to Fe(II) by around D800 for columns $100 \mathrm{mM}$ and $32 \mathrm{mM}$, and thus no longer served as the TEA for U(IV) reoxidation. The relative order of $\mathrm{U}$ effluent concentrations among the columns remained the same, consistent with enhanced $\mathrm{U}$ solubility with higher concentrations of bicarbonate. 
The bicarbonate concentrations in effluents from columns $6 \mathrm{mM}$ and $0 \mathrm{mM}$ were low, reflecting the low/zero OC influx. In the case of zero OC inflow, the effluent bicarbonate concentrations in the $\mathrm{mM}$ range indicated that oxidation of $\mathrm{OC}$ from soil organic matter and microbial biomass accumulated during phase I. Throughout most of this experiment, influents were prepared with water containing $0.14 \mathrm{mM} \mathrm{O}_{2}$ (undersaturated with respect to atmospheric $\mathrm{O}_{2}$ ). Before ending the experiment, we tested the responsiveness of the sediments to influxes of air-equilibrated $(0.26 \mathrm{mM} \mathrm{O})$ solutions. At D1080 three pore volumes of air-equilibrated influents were injected with all other chemical compositions remaining the same. The effluent U concentrations for the two higher OC supply columns were not affected by the increased influx of $\mathrm{O}_{2}$, but the two columns supplied with lower OC levels exhibited increases in effluent $\mathrm{U}$ concentrations. Given their long term with low/zero OC supply, these latter two column sediments apparently had less capacity for sustaining reducing conditions. Redox potential data presented in a later section also indicate gradual oxidation in columns $6 \mathrm{mM}$ and $0 \mathrm{mM}$. 

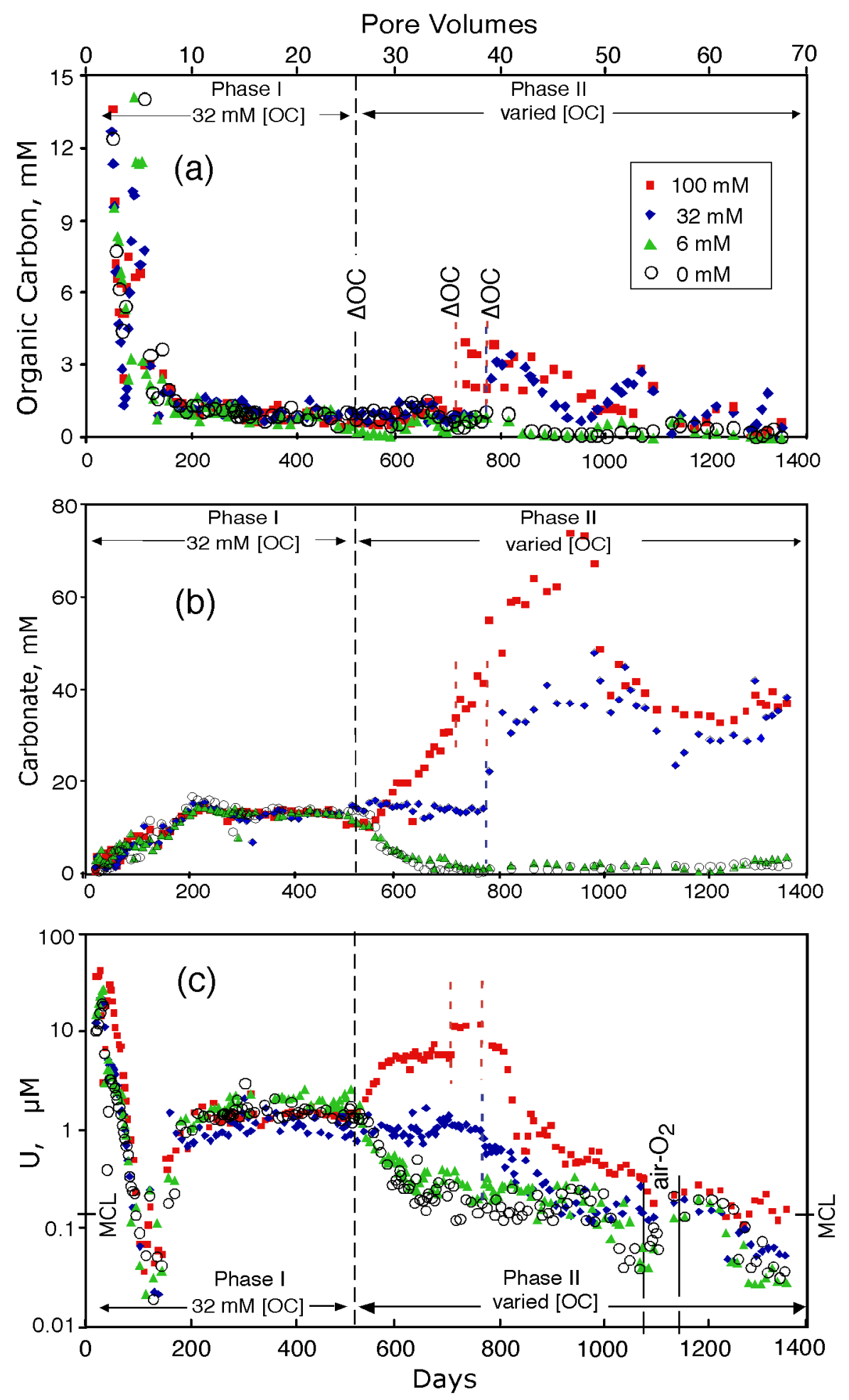

Figure 1. Effluent OC, bicarbonate, and U concentrations (all relative uncertainties < 10\%) from 4 sediment columns. (a) OC trends show $97 \%$ of injected lactate was being consumed, except for two columns when very high concentrations of OC were injected. " $\triangle O C$ " indicates times when influent OC concentrations were changed (Table 1). (b) Bicarbonate concentrations 
resulting from microbial respiration showed increases to $15 \mathrm{mM}$ in Phase I, and variations proportionally responding to the influent OC concentrations in Phase II. (c) U concentrations in effluents showing initial rapid reduction and reoxidation in Phase I, and varied responses to OC concentration changes in Phase II. The interval within Phase II with air $\mathrm{O}_{2}$ equilibrated influent solutions is indicated along the time axis. The U MCL of $0.126 \mu \mathrm{M}$ is indicated on the $\mathrm{y}$-axis.

Bioreduced Fe(II) in the Effluents and Sediments. Iron concentrations were measured periodically from D440 to D960 on effluents collected in acidified vials because it can be a useful indicator of Fe(III) reduction occurring in sediments (Figure 2). The effluents obtained on D440 (Phase I) contained $\mathrm{Fe}^{2+}$ concentrations greatly exceeding values for equilibrium with respect to siderite (18), showing that all sediments were actively undergoing Fe(III) reduction, some of which could support U(IV)-reoxidation. At D560 (50 days and 2.5 PV into Phase II), changes in effluent $[\mathrm{Fe}]$ reflected responses to changes in OC supply, with increased Fe(III) reduction and $\mathrm{U}(\mathrm{IV})$ reoxidation for column $100 \mathrm{mM}$, and much decreased Fe(III) reduction for columns 6 and $0 \mathrm{mM}$. For column $32 \mathrm{mM}$, decreased Fe(III) reduction was observed starting from D560 and continued toward the end, although this column was provided with an increased OC supply at D780. Decreases in available reactive Fe(III) may explain why the OC increase and resulting (bi)carbonate concentration increase (Figure 1b) did not result in increased effluent [U] (Figure 1c) from that column. Upon depletion (reduction) of the reactive poorly crystalline Fe(III) fraction, no other TEAs would be present to support U(IV) reoxidation. All the effluent Fe data after D560 showed time trends of decreasing concentrations. After D900 effluent [Fe] became $\leq$ $0.02 \mu \mathrm{M}$ (the detection limit), indicating significant decreases in rates of $\mathrm{Fe}(\mathrm{III})$ reduction, even at the highest OC supply rate. 


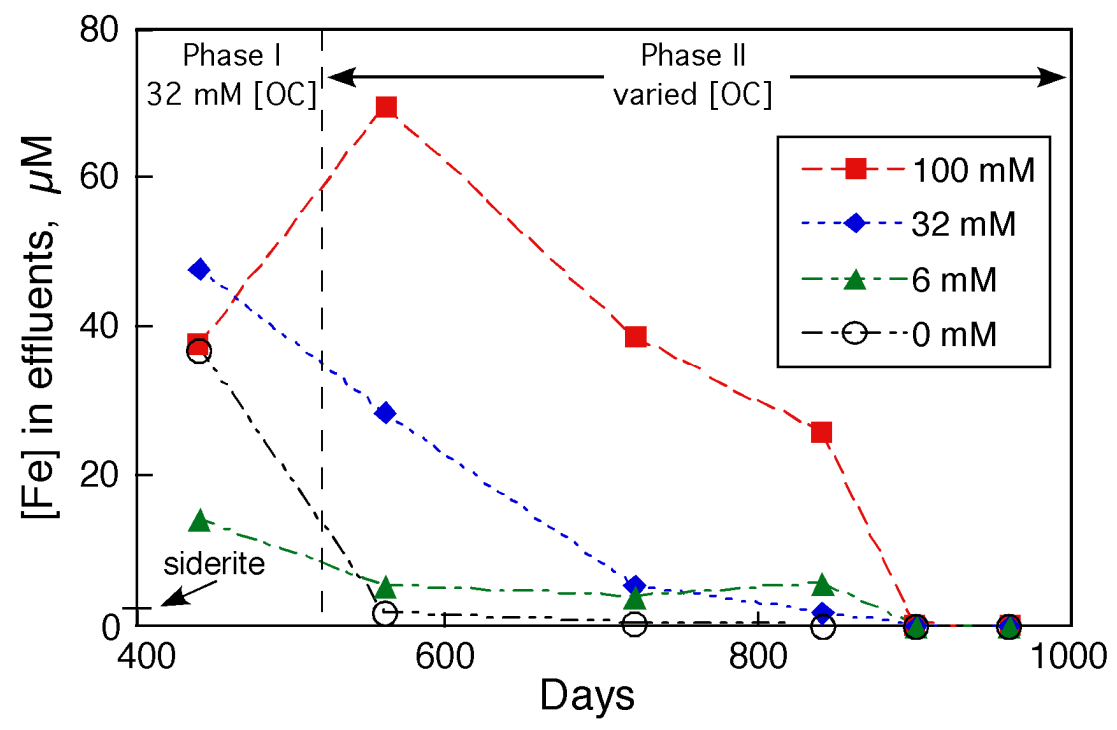

Figure 2. Time trends in effluent $\mathrm{Fe}$ concentrations. The concentration of $\mathrm{Fe}^{2+} \approx 2 \mu \mathrm{M}$ for equilibrium with siderite under characteristic Phase I conditions ( $\mathrm{pH} 7.4,15 \mathrm{mM} \mathrm{HCO}_{3}{ }^{-}$) is indicated on the y-axis. Effluent Fe concentrations in excess of this level are indicative of rapid reductive $\mathrm{Fe}(\mathrm{III})$ dissolution in each sediment column during phase I, and in the $32 \mathrm{mM}$ and 100 $\mathrm{mM}$ columns during the first half of Phase II.

Increases in microbially reduced Fe(II) in the reacted sediments were determined through measuring HCl-extractable $\mathrm{Fe}(\mathrm{II})$ (Figure 3). An additional data point presented in Figure 3 shows the total Fe in the sediment, $786.0 \pm 1.8 \mathrm{mmol} \mathrm{kg}^{-1}(4.39 \pm 0.01$ mass\%, X-ray fluorescence analysis). The original sediment (D0) had an HCl-extractable Fe(II) concentration of 0.9 mmol $\mathrm{kg}^{-1}$, and a hydroxylamine-reducible Fe(III) concentration of $9.0 \mathrm{mmol} \mathrm{kg}^{-1}$. The hydroxylaminereducible $\mathrm{Fe}(\mathrm{III})$ has been considered an indicator of $\mathrm{Fe}(\mathrm{III})$ available for microbial reduction (14), and amounted to $1.1 \%$ of the total iron for the original sediment. At D900, data of extracted $\mathrm{Fe}$ (II) are presented at the top of the figure. These sediment samples were collected from top surface of each column (vertical distance $20 \mathrm{~cm}$ ). The extractable D900 $\mathrm{Fe}(\mathrm{II}) / \mathrm{Fe}(\mathrm{III})$ levels are $110.4 / 0.28,152.8 / 0.22,61.2 / 0.12$, and $76.6 / 0.002 \mathrm{mmol} \mathrm{kg}^{-1}$ for the $100,32,6$, and $0 \mathrm{mM}$ columns, respectively. Relative to the D0 Fe(II) value $\left(0.9 \mathrm{mmol} \mathrm{kg}^{-1}\right)$, these D900 indicators of microbial reduced $\mathrm{Fe}(\mathrm{II})$ are large, and roughly proportional to the OC supply rates. Comparing 
the Fe(II) data from Day 900 (up to $153 \mathrm{mmol} \mathrm{kg}{ }^{-1}$ ) with the D0 extracted Fe(III) $\left(9.0 \mathrm{mmol} \mathrm{kg}^{-}\right.$ ${ }^{1}$ ), shows that the actual microbially-reducible ferric iron fraction was much larger than that by the hydroxylamine-reduction method estimated.

At D1400 (end of the experiment), each column was sectioned into five segments and one sediment sample was collected from each segment. The extractable Fe(II) data are presented in Figure 3 as concentration profiles along the column (flow direction upwards), connected with solid lines. The values of hydroxylamine-reducible Fe(III) at D1400 are very low (the majority $\leq 1$ mmol kg${ }^{-1}$ ) relative to the $\mathrm{Fe}(\mathrm{II})$ concentrations and no exhibited spatial trend, thus are not plotted. The Fe(II) data show a clear trend of increased microbial reduced Fe(II) (from 100 to 600 mmol $\mathrm{kg}^{-1}$ ) with increased OC supplied to the sediment. The amounts of microbial reduced Fe(II) are very large, with $10-50 \%$ of the total iron $\left(786 \mathrm{mmol} \mathrm{kg}^{-1}\right)$ in the sediment having been reduced. The bottom end of column $100 \mathrm{mM}$ yielded very high concentrations of reduced $\mathrm{Fe}(\mathrm{II})$, amounting to as much as $80 \%$ of the sediment total Fe. It should be noted that these Fe-extraction data were all obtained though analyses of triplicate samples, with standard deviations $\leq 10 \%$ (the majority of them $<6 \%$ ), and spike recoveries $100 \pm 3 \%$. These data (from effluents and sediments) collectively provide evidence supporting our hypothesis that a Fe(III) fraction capable of Ureoxidation persisted throughout Phase I and the early portion of Phase II. It should be noted that this Fe fraction capable of reoxidizing $\mathrm{U}$ is limited to amorphous $\mathrm{Fe}(\mathrm{III})$ and ferrihydrite, and that other common $\mathrm{Fe}(\mathrm{III})$ oxyhydroxides and oxides such as goethite and hematite are incapable of driving U-reoxidation $(13,19)$. In a similar study, direct measurements of Fe oxidation states using X-ray absorption spectroscopy showed that $12 \%$ of the $\mathrm{Fe}(\mathrm{III})$ in this sediment was reduce up to 400 days (20). These results collectively indicate that only a small Fe(III) fraction is readily available for bioreduction and for U-reoxidation, and that a much larger $\mathrm{Fe}(\mathrm{III})$ fraction is gradually bioreduced over longer times (1400 days). 


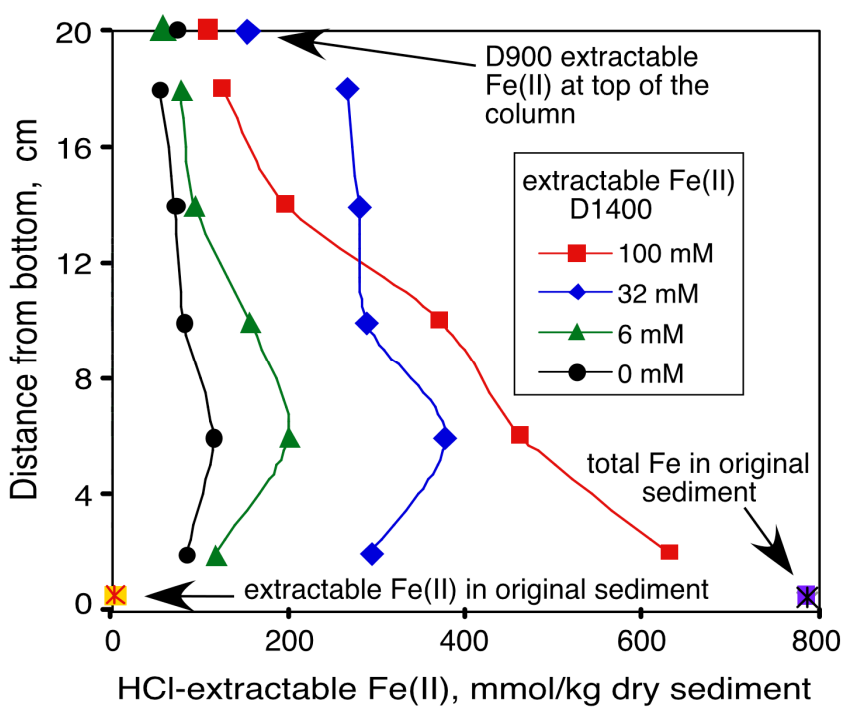

Figure 3. $\mathrm{HCl}$-extractable $\mathrm{Fe}(\mathrm{II})$ in column sediments at different times. Day $900 \mathrm{Fe}$ (II) data appear at the top of the figure (only one sample was collected from the top surface of each column). Day $1400 \mathrm{Fe}$ (II) data are from 5 samples along the length of each sediment column. The total Fe content of the original sediment was obtained by X-ray fluorescence.

Changes of Sediment Redox Potentials. Platinum electrode measurements of sediment redox potential profiles are presented in Figure 4a-d. The measurements were conducted at four time points during the final 240 days, through 6 electrodes distributed along the length of each column. The data show generally more oxidized conditions at the first time point, D1160, except for column $0 \mathrm{mM}$. These somewhat higher D1160 Eh values may have resulted from injection of air-equilibrated influent solutions (during days 1080-1140). Although the D1160 Eh values were relatively higher than that at the later days for the two columns receiving higher OC, the Eh profiles remained strongly reducing, and the effluent $\mathrm{U}$ was maintained at low concentrations during the final 300 days (Figure 1c). Upon resuming injection of influents under-saturated with respect to atmospheric $\mathrm{O}_{2}$, the Eh values decreased for all the columns except column $0 \mathrm{mM}$. Although effluent $U$ concentrations remained low at the end of the experiments, the trends in increased Eh indicate that $\mathrm{U}$ re-oxidization and remobilization might have occurred in the $0 \mathrm{mM}$ 
column if the experiment were continued longer because microbial activity will eventually deplete the available organic carbon.
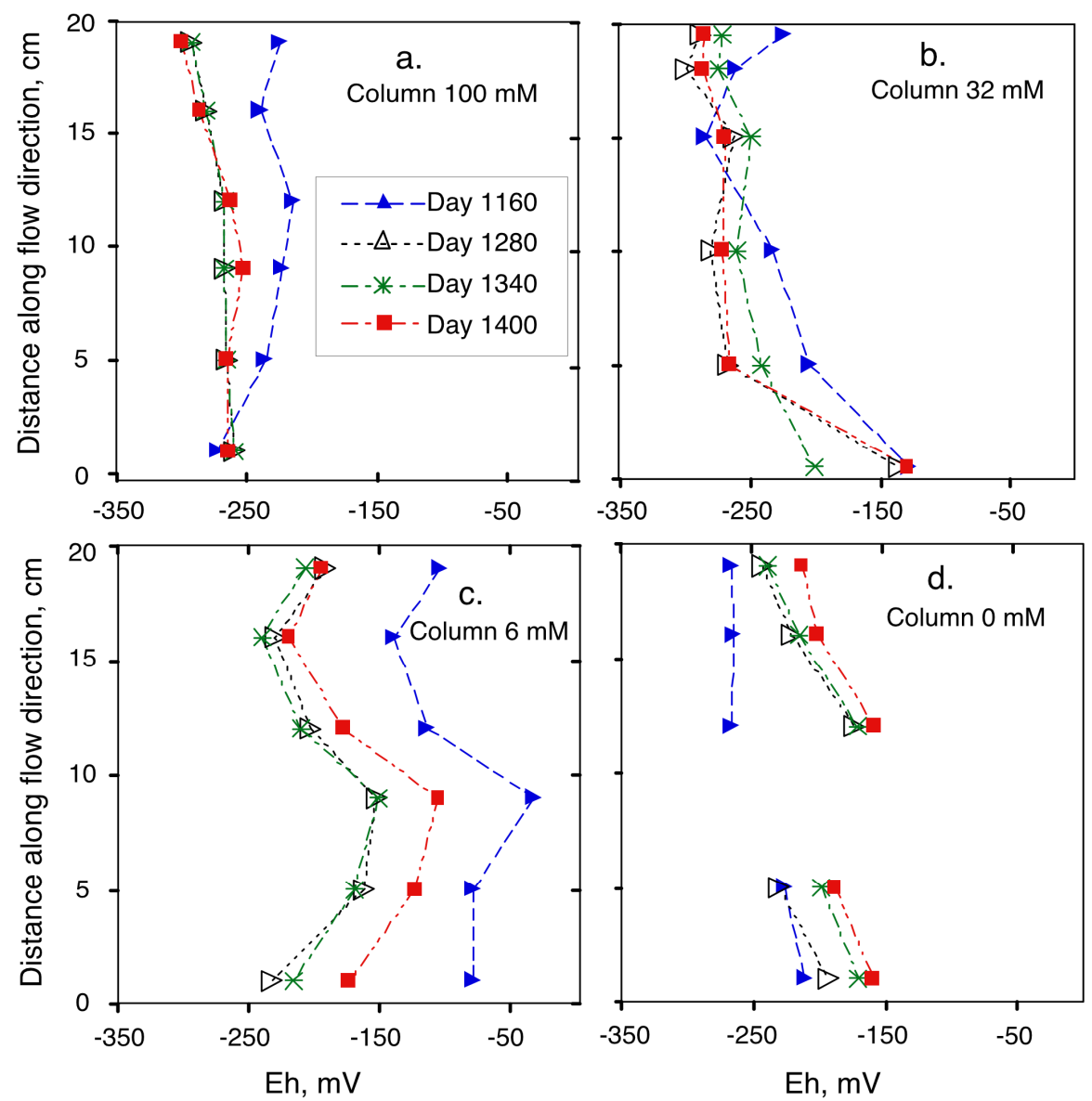

Figure 4. Direct redox potential measurements of the 4 sediment columns conducted for 4 times within the final 240 days. Note that the middle electrode of column $0 \mathrm{mM}$ was damaged. The first time point, D1160, was obtained 20 days after the injection of 3 PVs of air-equilibrated influents.

Carbonate-extractable U(VI). In Figure 5, the far right dashed black line indicates the total U concentration in original sediment $(0.86 \pm 0.03 \mathrm{mmol} / \mathrm{kg}$ sediment, by XRF and KPA analyses of acid-digested sediment). The $U$ remaining in sediments at the end of this study was calculated based on subtraction of $U$ removed in effluent solutions (Figure 1c) from the total $U$ 
concentration in original sediment. These calculated final $U$ concentrations are $\underline{\underline{\underline{\underline{p}}}} \overline{\mathrm{p}}, 0.818$, 0.816 , and $0.824 \mathrm{mmol} \mathrm{kg}^{-1}$ for columns $100,32,6$, and $0 \mathrm{mM}$, respectively. After 1400 days of permeation the total $\mathrm{U}$ in these sediments are reduced by $11 \%$ to $4 \%$ for columns 100 to $0 \mathrm{mM}$, respectively. These values further underscore the fact that the highest level of OC supply caused the most $U$ mobilization instead of $U$ immobilization in these reducing sediments. The carbonate-extractable U(VI) concentrations showed good reproducibility, relative variability among triplet extractions of subsamples being less than 5\%. The purple dashed line indicates the carbonate-extracted $\mathrm{U}(\mathrm{VI})\left(0.54 \mathrm{mmol} \mathrm{kg}^{-1}\right)$ from the original sediment, which amounts to $62 \%$ of the total sediment $U$. The carbonate-extracted U(VI) from the four column sediments at the end of the experiment are presented as profiles of five sampling locations from each column. Note that theses data show increased extractable U(VI) with decreased OC supply. Using the average value of each column to compare with the total $U$ in the original sediment, we obtained carbonate-extractable U(VI) of the reacted sediments under different OC supply rates: 20\%, 26\%, $35 \%$, and $43 \%$ for columns $100,32,6$, and $0 \mathrm{mM}$. This trend of carbonate-extractable U(VI) increase with decreasing OC supply rates is consistent with redox potential data in Figure 4, suggesting $9 \%$ and $14 \%$ of originally microbial reduced U(IV) were reoxidized in the columns 6 and $0 \mathrm{mM}$, respectively, in comparison with the column $32 \mathrm{mM}$. These results also show that effluent $U$ concentrations provide an incomplete understanding of $U$ status at the time of Phase II. 


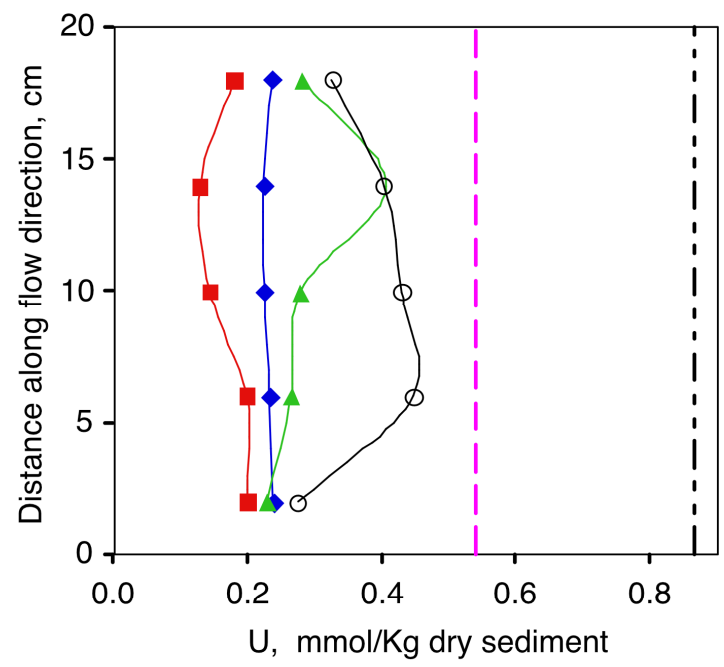

\begin{tabular}{|c|c|}
\hline $\begin{array}{l}\longrightarrow-100 \mathrm{mM} \\
--32 \mathrm{mM}\end{array}$ & 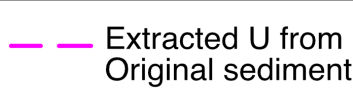 \\
\hline $\begin{array}{l}-6 \mathrm{mM} \\
-0 \mathrm{mM}\end{array}$ & $---\sum_{\text {Sediment }} \cup$ in Original \\
\hline
\end{tabular}

Figure 5. Carbonate-extractable U(VI) from reacted sediments at D1400, compared with U concentrations in the original sediment.

Molecular analysis of microbial and Geobacteraceae specific activity. Consistent with OC supply rate, total microbial activity (sediment RNA concentrations) was higher in $100 \mathrm{mM}$ columns compared with 6 and $0 \mathrm{mM}(32 \mathrm{mM}$ column was not analyzed for microbiology microbial activity also declined with distance from the inflow. We specifically assayed the activity of Geobacteraceae due to their recognized importance as metal and radionuclide reducers in subsurface sediments. Their abundance has been demonstrated to correlate with iron and uranium reduction (21). Previous studies using FRC sediments have shown that composition of the active microbial community (RNA) differs from DNA-based community analysis (22) and that microbial communities vary spatially in columns (23). Quantitative PCR analysis of Geobacteraceae populations in these columns revealed a decline in activity (16S rRNA) with distance from the inflow similar to total microbial activity (Fig. 6A and B). Significantly, 
Geobacteraceae activity was similar in some sections of columns receiving low or no OC to those receiving $100 \mathrm{mM}$ OC. Maintenance over 2.5 years of active Geobacteraceae in columns without OC supply was unexpected. As all columns originally received $32 \mathrm{mM}$ OC for the first 500 days substantial microbial biomass would have accumulated (24). Therefore continued Geobacteraceae activity after almost 2.5 years without OC may have been sustained through cryptic growth, whereby microbial communities recycle nutrients from dying bacteria that leak metabolizable substrates (25). Geobacteraceae activity correlated strongly with $\mathrm{HCl}$-extractable $\mathrm{Fe}(\mathrm{II})(\mathrm{r}=0.79$, $\mathrm{p}<0.05)$. The Geobacteraceae activity continued through the end of the experiments, although effluent Fe(II) concentrations were very low during the second half of Phase II. The syntrophic mode of electron transfer could have also contributed to Geobacteraceae survival during periods of low bio-available Fe.
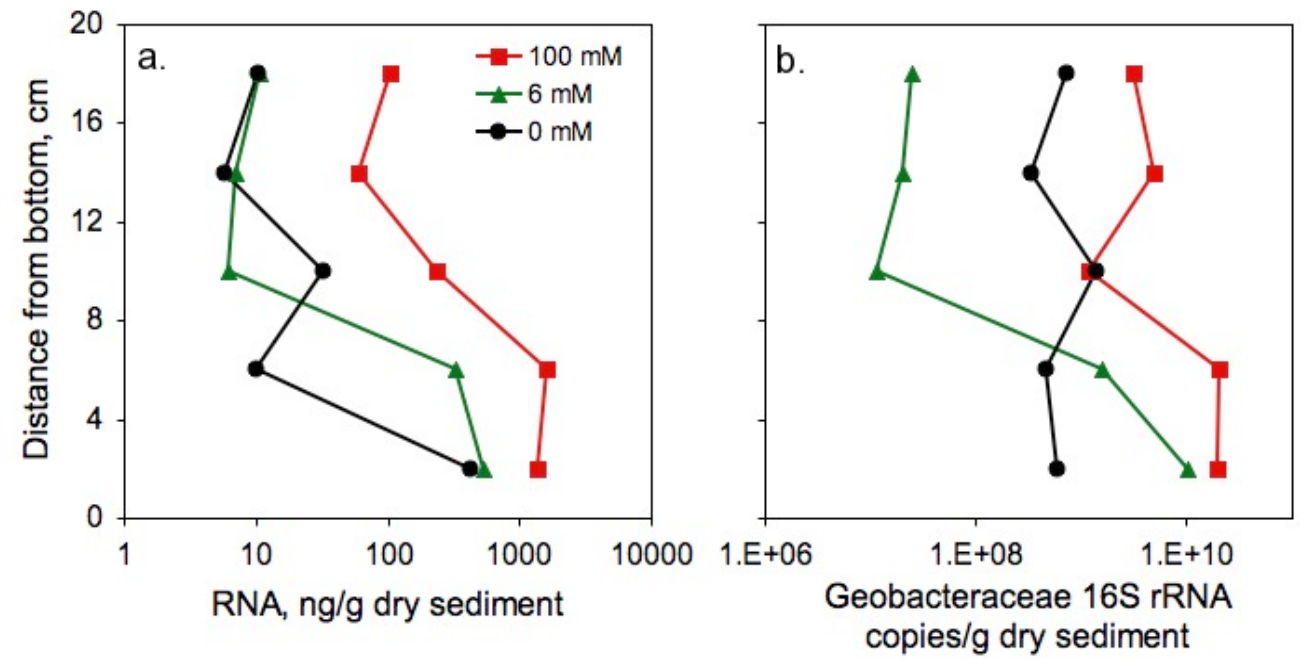

Figure 6. (a) Concentration of RNA in sediment extracted from column sections as a proxy for microbial activity (b) specific activity of Geobacteraceae species through column sections. All data represent the mean of technical replicates performed in triplicate. 
Implications for in-situ $\mathbf{U}$ remediation. Several findings from this 3.8 year laboratory simulation are important when considering application of OC-stimulated U bioremediation as a potential remediation strategy.

1. After initial U(VI) microbial reduction has been achieved, the OC supply rate is a key factor controlling the degree of $\mathrm{U}$ reoxidation/remobilization when reactive $\mathrm{Fe}(\mathrm{III})$ is still available. Elevated bicarbonate concentrations resulting from OC stimulated microbial respiration cause $\mathrm{U}(\mathrm{IV})$ reoxidation/remobilization even under reducing condition.

2. The reducible ferric iron concentration can be very large (much larger than we previously understood), especially relative to levels of $U$ contamination.

3. Lower OC supply rates prevented carbonate driven U-remobilization for the moment within the experimental time frame. However, the sediment had become more oxidized and U(VI) ratio had significantly increased. The low OC supply rates we tested could not sustain the sediment being reduced for long times, even under the experiment conditions of excluding TEAs such as $\mathrm{NO}_{3}{ }^{-}\left(\mathrm{NO}_{2}{ }^{-}\right)$and $\mathrm{SO}_{4}{ }^{2-}$.

Acknowledgments. This work was carried out under U. S. Department of Energy Contract No. DE-AC02-05CH11231. Funding from the U. S. Department of Energy, Environmental Remediation Science Program (ERSP) is gratefully acknowledged.

\section{Supporting Information Available}

Additional materials are available free of charge via the Internet at http://pubs.acs.org. 


\section{Literature Cited}

(1) Langmuir, D. Aqueous environmental geochemistry; Prentice Hall: Upper Saddle River, NJ. . 1997.

(2) Lovley, D. R.; Phillips, E. J. P.; Gorby, Y. A.; Landa, E. R. Microbial reduction of uranium. Nature 1991, 350, 413-416.

(3) Lovley, D. R.; Roden, E. E.; Phillips, E. J. P.; Woodward, J. C. Enzymatic iron and uranium reduction by sulfate-reducing bacteria. Marine Geology 1993, 113, 41-53.

(4) Ganesh, R.; Robinson, K. G.; Reed, G. D.; Sayler, G. S. Reduction of hexavalent uranium from organic complexes by sulfate- and iron-reducing bacteria. Appl. Environ. Microbiol. 1997, 63, 4385-4391.

(5) Fredrickson, J. K.; Zachara, J. M.; Kennedy, D. W.; Duff, M. C.; Gorby, Y. A.; Li, S. W.; Krupka, K. M. Reduction of U(VI) in goethite ( $\alpha-\mathrm{FeOOH})$ suspensions by a dissimilatory metalreducing bacterium. Geochim. Cosmochim. Acta 2000, 64, 3085-3098.

(6) Uhrie, J. L.; Drever, J. I.; Colberg, P. J. S.; Nesbitt, C. C. In situ immobilization of heavy metals associated with uranium leach mines by bacterial sulfate reduction. Hydrometallurgy 1996, 43, 231-239.

(7) Abdelouas, A.; Lu, Y.; Lutze, W.; Nuttall, H. E. Reduction of U(VI) to U(IV) by indigenous bacteria in contaminated ground water. J. Contam. Hydrol. 1998, 35, 217-233. (8) Anderson, R. T.; Vrionis, H. A.; Ortiz-Bernad, I.; Resch, C. T.; Long, P. E.; Dayvault, R.; Karp, K.; Marutzky, S.; Metzler, D. R.; Peacock, A.; White, D. C.; Lowe, M.; Lovley, D. R. Stimulating the in situ activity of Geobacter species to remove uranium from the groundwater of a uranium-contaminated aquifer. Appl. Environ. Microbio. 2003, 69, 5884-5891.

(9) Casas, I.; Gimenez, J.; Marti, V.; Torrero, M. E.; de Pablo, J. Kinetic studies of unirradiated UO2 dissolution under oxidizing conditions in batch and flow experiments. Radiochim. Acta 1994, 66/67, 23-27. 
uranium solubility during bioremediation of uranium-contaminated subsurface sediments.

Environ. Microbiol. 2002, 4, 510-516.

(11) Senko, J. M.; Istok, J. D.; Suflita, J. M.; Krumholz, L. R. In-situ evidence for uranium immobilization and remobilization. Environ. Sci. Technol. 2002, 36, 1491-1496.

(12) Moon, H. S.; Komlos, J.; Jaffe, P. R. Uranium reoxidation in previously bioreduced sediment by dissolved oxygen and nitrate. Environmental Science and Technology 2007, 41, $4587-4592$.

(13) Wan, J.; Tokunaga, T. K.; Brodie, E. L.; Wang, Z.; Zheng, Z.; Herman, D. J.; Hazen, T.

C.; Firestone, M. K.; Sutton, S. R. Reoxidation of bioreduced uranium under reducing conditions. Environmental Science and Technology 2005, 39, 6162-6169.

(14) Lovley, D. R.; Phillips, E. J. P. Rapid assay for microbially reducible ferric iron in aquatic sediments. Applied and Environmental Microbiology 1987, 53, 1536-1540.

(15) Zhou, P.; Gu, B. Extraction of oxidized and reduced forms of uranium from contaminated soils: Effects of carbonate concentration and pH. Environmental Science and Technology 2005, 39, 4435-4440.

(16) Team, R. D. C.; R Foundation for Statistical Computing: Vienna, Austria, 2008.

(17) U.S. Environmental Protection Agency's Maximum Contaminant Level for U Amendment to 40 CFR Part 141, 65 FR 76708. 2000.

(18) Jensen, D. L.; Boddum, J. K.; Tjell, J. C.; Christensen, T. H. The solubility of rhodochrosite $(\mathrm{MnCO} 3)$ and siderite $(\mathrm{FeCO} 3)$ in anaerobic aquatic environments. Applied Geochemistry 2002, 17, 503-511.

(19) Ginder-Vogel, M.; Criddle, C. S.; Fendorf, S. Thermodynamic constraints on the oxidation of biogenic UO2 by Fe(III) (hydr)oxides. Environmental Science and Technology 2006, $40,3544-3550$. 
Real-time X-ray absorption spectroscopy of uranium, iron, and manganese in contaminated sediments during bioreduction. Environmental Science and Technology 2008, 42, accepted.

(21) Holmes, D. E.; Finneran, K. T.; O'Neil, R. A.; Lovley, D. R. Enrichment of members of the family Geobacteraceae associated with stimulation of dissimilatory metal reduction in uranium-contaminated aquifer sediments. Appl Environ Microbiol 2002, 68, 2300-2306.

Akob, D. M.; Mills, H. J.; Kostka, J. E. Metabolically active microbial communities in uranium-contaminated subsurface sediments. FEMS Microbiol Ecol 2007, 59, 95-107.

$$
\text { Michalsen, M. M.; Peacock, A. D.; Spain, A. M.; Smithgal, A. N.; White, D. C.; }
$$

Sanchez-Rosario, Y.; Krumholz, L. R.; Istok, J. D. Changes in microbial community composition and geochemistry during uranium and technetium bioimmobilization. Appl Environ Microbiol 2007, 73, 5885-5896.

(24) Brodie, E. L.; Desantis, T. Z.; Joyner, D. C.; Baek, S. M.; Larsen, J. T.; Andersen, G. L.; Hazen, T. C.; Richardson, P. M.; Herman, D. J.; Tokunaga, T. K.; Wan, J. M.; Firestone, M. K. Application of a high-density oligonucleotide microarray approach to study bacterial population dynamics during uranium reduction and reoxidation. Appl Environ Microbiol 2006, 72, 62886298.

(25) Ryan, F. J. Bacterial mutation in a stationary phase and the question of cell turnover. $J$ Gen Microbiol 1959, 21, 530-549.

\section{Brief}

The extent of reoxidation and remobilization of previously bioreduced U(IV) was proportional to the organic carbon supply rate before reactive $\mathrm{Fe}(\mathrm{III})$ was reduced. 